UNIO - EU Law Journal. Vol. 3, No. 2, July 2017, pp 20-33.

®2017 Centre of Studies in European Union Law

School of Law - University of Minho

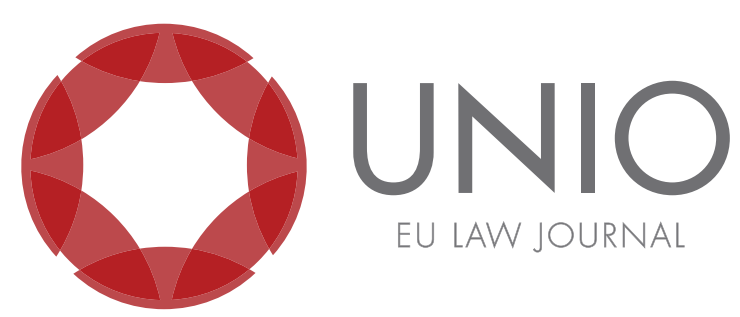

\title{
The CJEU's judgment in $C H E Z$ and indirect discrimination by association: an analysis of progress in combating racial or ethnic discrimination in the European Union
}

\author{
Mariana Schafhauser Boçon*
}

ABSTRACT: Since the entry into force of the Directive 2000/43/EC of 29 June 2000 (implementing the principle of equal treatment between persons irrespective of racial or ethnic origin), Member States have been the subject of reports from the European Commission in 2006 and 2014, from which we can analyze the contributions of the Directive in promoting equality. The obstacles faced in the interpretation of concepts such as direct discrimination, indirect discrimination, and positive actions are worthy of note. In addition, what is also important to highlight is the main ethnic groups that suffer from discriminatory practices, as is the case of individuals belonging to the Roma ethnic group in several countries of the European Union. In this text, the author shows the extent to the CJEU's judgment CHEZ (C-83/14) is an important milestone for the implementation of the Directive 2000/43/EC, by presenting a new interpretation, namely on the possibility of indirect discrimination by association, as this opens up a new understanding of discrimination situations that can significantly impact the current promotion of equal treatment for all persons in the European Union.

KEYWORDS: Directive 2000/43/EC - principle of non-discrimination - racial or ethnic origin - judgment CHEZ (C-83/14) - discrimination by association.

\footnotetext{
* Master's student in Human Rights at University of Minho. This work in its version in Portuguese was awarded the Prize António de Sousa Franco by the University of Lisbon (category: "formação" / "training”).
} 


\section{The principle of equal treatment and the Directive 2000/43/EC}

\section{The Directive $2000 / 43$ /EC of 29 June 2000}

The idea of a right to equality and to protection against discrimination for all people is a universal right recognized by the main international instruments for the protection of human rights. In the specific context of the European Union, under the terms of Article 21 (1) of the Charter of Fundamental Rights of the European Union (CFREU), a general principle of non-discrimination is affirmed, which has led to the development of other key normative instruments on the subject, such as the Directive 2000/43/EC of 29 June 2000, implementing the principle of equal treatment between persons irrespective of racial or ethnic origin and the Directive 2000/78/EC of 27 November 2000, that establishes a framework for the general principle of equal treatment in employment and occupation. ${ }^{1}$

The Directive 2000/43/EC aims to establish specific actions in the field of discrimination on grounds of racial or ethnic origin to guarantee the objectives of the European Union and the development of democratic, tolerant and supportive societies. With this objective, this directive defines the concept of discrimination in its Article 2, which specifies that the principle of equal treatment presupposes the absence of any form of direct or indirect discrimination based on racial or ethnic origin throughout the (then) European Community.

According to its Article 2 (2) (a), direct discrimination shall be deemed to exist where, on account of racial or ethnic origin, a person is treated less favorably than that which is, has been, or may be given to another person in a comparable situation. The notion of indirect discrimination is found in Article 2 (2) (b), which provides that a situation of indirect discrimination is to be considered where an apparently neutral provision, criterion or practice places persons of a racial or ethnic origin at a disadvantage compared to other persons, unless that provision, criterion or practice is objectively justified by a legitimate aim and the means of achieving it are appropriate and necessary.

It is the responsibility of the Member States, in particular that of their judicial bodies, to analyse the facts from which it can be deduced that there has been direct or indirect discrimination and they may stipulate that indirect discrimination can be determined by any means of proof, including statistical data.

Regarding its scope of application, Directive 2000/43/EC is innovative when considering that specific actions in the field of discrimination on grounds of racial or ethnic origin apply in both, the public and private sectors and in situations that go beyond the traditional field of access to employment, extending to education, social security, health care, social benefits and access to and supply of goods and services such as housing. ${ }^{2}$

However, the directive states that measures to prevent or compensate for disadvantages suffered by a group of persons of a racial or ethnic origin whose main purpose is to promote the special needs of such persons cannot be undermined

\footnotetext{
1 For futher information see Mariana Canotilho, "Brevíssimos apontamentos sobre a não discriminação no Direito da União Europeia", Revista Julgar 14 (2011): 101-111, http://julgar. pt/wp-content/uploads/2014/07/05-DEBATER-Mariana-Canotilho-A-n\%C3\%A3-odiscrimina $\%$ C3\%A7\%C3\%A3o-no-dire.pdf (accessed February 22, 2017).

${ }^{2}$ See Article 3 of the Directive 2000/43/EC.
} 
by the principle of prohibition of discrimination. It establishes that differences of treatment may be justified in very specific circumstances where a characteristic related to racial or ethnic origin constitutes a genuine and determining requirement for the pursuit of professional activity, provided that the objective is legitimate and the requirement is proportionate.

The Directive 2000/43/EC lays down a minimum requirement of protection against discrimination, so that Member States may introduce or maintain provisions which are more favorable than those defined in the directive. It also states that it is for the Member States to take the necessary measures in their internal order to ensure that all persons who are prejudiced by non-application of the principle of equality may resort to judicial or administrative proceedings, including the involvement of associations, organisations or other legal entities which have a legitimate interest in enforcing the provisions of the directive.

With regard to the procedural aspect, the directive requires Member States to ensure that when a person, considering himself to be harmed by non-application of the principle of equality, submits before the competent body, facts that constitute the presumption of discrimination, the burden of proving that there has been no breach of the principle of equal treatment must lie with the defendant, except in criminal proceedings and in cases where the investigation of the facts falls to the court or to the competent body. It is also for the Member States to introduce into their legal systems the measures necessary to protect individuals from unfavorable treatment which could arise in response to a complaint or action requiring compliance with the principle of equal treatment.

The directive also sets out important points for the promotion of equal treatment by disseminating information on citizens' rights and promoting dialogue with organisations in society. That way, Member States have a duty to inform people of the provisions adopted in the scope of Directive 2000/43/EC and take appropriate measures to promote social dialogue between the social partners in order to make an exchange of experience, good practices, and agreements in the context of collective bargaining. In addition to this dialogue with existing social organisations, the directive stipulates that Member States shall designate one or more bodies to promote equal treatment of all persons, without any discrimination based on racial or ethnic origin, and to provide independent assistance to victims of discrimination, to conduct independent surveys on discrimination and to publish reports and make recommendations on any issue related to such discrimination.

On the penalties to be applied for breaches of the national provisions adopted pursuant to the directive, it was established that the Member States will determine the systems of those penalties, which may include the payment of compensation to the victim in an effective, proportionate and dissuasive manner.

Since the entry into force of the Directive 2000/43/EC, two reports have been adopted by the Commission to the European Parliament and the Council, one in 2006 and the other in 2014. These reports will be now analysed in order to understand the impact of the directive in the Member States, the objectives achieved and the obstacles encountered. 


\section{Communication from the Commission COM (2006) $643 \mathrm{final}^{3}$}

Although many Member States have not provided the Commission with useful data for the Communication, it is clear from the information provided that although Member States are familiar with the obligation of equal treatment with regard to discrimination between men and women, the Directive 2000/43/EC was important in extending this principle to new areas such as access to goods and services. This has led some Member States to adopt new and comprehensive anti-discrimination legislation while others have had to introduce changes in legislation to better comply with the terms of the directive. With all these legislative changes, important issues have arisen for effective transposition of the directive into national legal orders, such as the definition of direct discrimination, indirect discrimination, the limit of exceptions to the principle of non-discrimination and the determination of the burden of proof more favorably to victims of discrimination.

Regarding the right to reparation, it can be seen that many victims of racial or ethnic discrimination do not file a complaint in court because of the costs they have to bear and because of the fear of reprisal, preferring to seek help from organisations and NGOs operating in the area of equality. In this respect, it can be seen that in the complaints that were presented, statistically, Roma people are more represented in them. According to the Communication, this data "shows that the Directive is being used effectively to combat discrimination against this group". ${ }^{4}$

With regard to equality bodies, the report states that some Member States that already had gender equality entities have only expanded their powers, while others have preferred to create new entities and, while in some Member States, legal aid has been prioritised, others have sought to provide more incentives in the promotion of opportunities and prevention of discrimination, with awareness-raising activities, such as in Belgium, Cyprus and the United Kingdom, where the specific guidance for employers help them fulfill their legal obligations, while at the same time sensitising them to the problems of discrimination. In promoting the principle of equal treatment and combating discrimination, the directive emphasized the importance of the social partners and NGOs, in particular, through codes of conduct, collective agreements and the exchange of good practices.

In view of this situation, the Commission sets out in the Communication the question of positive action in order to distinguish them from measures of "positive discrimination", which are not compatible with the directive. Positive action measures seek to ensure full equality in practice by preventing or compensating individuals for inconveniences arising from a particular racial or ethnic origin, so that these disadvantaged groups have the same access conditions as others. Measures of "positive discrimination", however, give absolute and automatic preference to members of a particular group over others, without any justification other than them belonging to that group.

In addition, the report shows that specific measures to prevent or compensate for disadvantages related to discrimination on the basis of racial or ethnic origin vary from place to place, depending on which groups are most discriminated against in each region. In the terms presented in the report, there is a significant number of

\footnotetext{
${ }^{3}$ Communication from the Commission $\operatorname{COM}(2006) 643$ final, adopted by the Commission on 30 October 2006. accessed January 12, 2017. http://ec.europa.eu/transparency/regdoc/rep/1/2006/ EN/1-2006-643-EN-F1-1.Pdf.

${ }^{4}$ See Communication from the Commission $\operatorname{COM}(2006) 643$ final: 5.
} 
positive actions targeting Roma groups, such as Spain, Hungary and Slovakia. ${ }^{5}$ In the Netherlands, there are positive actions in the area of discrimination on grounds of sex, race and disability, but it must be proven to be a structural discrimination, whereas in Finland, positive actions are targeted specifically at the Sami people.

The Communication from the Commission concludes that Directive 2000/43/ EC represents a major step forward in the fight against racial discrimination in the European Union, leading to changes in national legal systems or even to the adoption of entirely new legislation. At the time of the report, the Directive had been in force for just over three years and the Court of Justice of the European Union had, hitherto, not been urged by the national courts to give preliminary rulings on any case on the subject of the directive.

Finally, the report identified the need to establish mechanisms and methods to better monitor the impact of national implementing measures, such as the creation of a statistical base. However, it has been pointed out that the scarcity of ethnic data in most Member States may be an obstacle to the effective transposition of Directive 2000/43/EC.

\section{Report from the Commission COM (2014) 2 final $^{6}$}

The Report from the Commission COM (2014) 2 final to the European Parliament and the Council was a joint report on the implementation of the Council Directive 2000/43/EC of 29 June 2000 and the Council Directive 2000/78/EC of 27 November 2000. In this work, we will focus on the common aspects of the two Directives and the specific aspects of the Directive 2000/43/EC discussed in that report.

Almost eight years after the first report, and thus, about eleven years after the entry into force of the Directive 2000/43/EC, the Commission verified in 2014, that the 28 Member States of the European Union have already transposed the directive and have already had greater experience in its application. Furthermore, the CJEU has been called upon by the Member States to cooperate to improve the interpretation given to the directive.

An examination of the experiences of individual Member States revealed that there were still difficulties in implementing the directive, such as the lack of awareness among European citizens of their rights in this area. One of the points made by the Commission is the lack of data made available by the Member States on equal treatment. Although the directive does not oblige Member States to collect these types of data, they do make a significant contribution to the quantification of discriminatory situations, to promote evidence in concrete cases, and to give visibility to the issue. The lack of data, on the other hand, makes it difficult to assess situations, especially when it comes to indirect discrimination, because when analysing the adverse effects of an apparently neutral measure on a particular group, statistical data gain a larger relevance. According to the report, most Member States accept statistical data to prove discrimination, but few collect data on equal treatment.

\footnotetext{
${ }^{5}$ In Slovakia, however, positive actions are considered as a specific means of addressing social exclusion of Roma groups, a controversial approach deemed unconstitutional by the Constitutional Court in the Judgment of 18.10.2004 (PL.US.8 / 04).

${ }^{6}$ Report from the Commission $\operatorname{COM}(2014) 2$ final, adopted by the Commission on 17 January 2014, accessed February 15, 2017, http://ec.europa.eu/justice/discrimination/files/com_2014_2_ en.pdf.
} 
Under the 2014 report, there were still a small number of complaints of discrimination, either in the initial complaint to the police or to equality bodies, or in legal proceedings. In this regard, the report presents as obstacles to access to justice $\imath$ ) the short deadlines for lodging complaints; ii) the costs of proceedings and the length of the proceedings and; iii) that there are dubious points regarding the practical availability of remedies and compliance with requirements of the Directive in Member States' sanctions, since national courts appear to have a tendency to apply the less severe sanctions provided for by the law, as well as the lower values of the compensation set. However, despite a small number of complaints and legal proceedings, the cases that have been in place since the last report have revealed a variety of situations in the case-law of the Member States' courts, with referral of cases to the CJEU in some Member States.

The report then, presents relevant aspects of the review which concern both the Directive 2000/43/EC and the Directive 2000/78/EC. The first aspect examined concerns surrounding the complex concept of indirect discrimination, whose correct transposition into national legal systems has been an obstacle to many Member States and is a subject of discussion in the 2006 report. With the transposition of Directive 2000/43/EC by all Member States, we have the concept already enshrined in the law, however, its practical application remains problematic, considering that the courts of some Member States have already raised issues such as the lack of clarity or incorrect interpretation of the concept, especially since many Member States have indicated that they have no case-law on the interpretation of the concept.

As regards the burden of proof, which is essential for ensuring that complaints of discrimination are dealt with properly before the courts and competent authorities, the report stated that some Member States still face difficulties in correctly reversing the burden, and Courts are unacquainted with this legal entity. In response to this difficulty already presented in the 2006 report, the Commission stated that it has promoted the correct application of the concept through the training of judges and practitioners in the Member States.

As for the other issue already addressed in the 2006 report, which concerns the two directives under consideration in the 2014 report, it also examines the status of the positive actions, which the Directives expressly authorise, but do not require the Member States to maintain or adopt. According to the report of 2014, almost all Member States have introduced some type of positive action for target groups. In the case of the Directive 2000/78/EC, these actions focused on the benefits of people with disabilities and under the Directive 2000/43/EC, for the benefit of Roma groups. In the first case, several Member States have reported on the definition of quotas for people with disabilities that must be respected by employers in the public sector, on the other hand, positive actions to benefit Roma communities cover more aspects of life in society, including four main sectors of national strategies for these populations: employment, education, housing and health care.

Still dealing with aspects relevant to the two directives, the report examines the issue of discrimination by association, bringing to the discussion the CJEU's Judgment Coleman, of 17 July 2008, case C-303/06, in which the CJEU found that the Directive 2000/78/EC protected the mother of a child with a disability in relation to employment harassment and discrimination, as those problems were due to the fact that she needed extra time to care for the child. ${ }^{7}$ In that judgment, the CJEU

\footnotetext{
${ }^{7}$ For further information see Declan O’Dempsey, "Coleman: the emerging philosophy of the
} 
considered that, in certain circumstances, discrimination on the basis of disability may also cover the discrimination that a person without disability suffers from being associated with a person with a disability.

Finally, the report points out that the two directives state that they apply equally to third-country nationals, even though they do not cover differences of treatment on grounds of nationality, nor do they affect the provisions governing the entry in the Member States of the European Union. Thus, it is understood that both Directives protect not only the citizens of the European Union, but all the persons in the Union, including stateless persons, who are particularly vulnerable to discrimination.

Concerning the specific aspects of the Directive 2000/43/EC, the report firstly notes that the directive does not define racial or ethnic origin, and it is for each Member State to decide whether or not to include the definition in their national legislation, so that some refer only to "ethnic origin" or "ethnicity".

As regards the substantive scope of the directive, one of the points under consideration is the notion of its application in cases of access to and supply of goods and provision of services made available in the public sector. The report complements what has already been examined in the 2006 report, noting that equality bodies have been set up in all Member States, many of which include the protection of discriminatory practices beyond racial or ethnic lines.

As a last point of analysis of the exclusive aspects of the Directive 2000/43/ EC, the report specifically examines the issue of the protection of Roma group under the Directive, as they form a particularly large and vulnerable ethnic group in discriminatory issues. According to the report, the Commission has already had to solve problems directly raised by national legislation. However, the problems of Roma communities are different, since they are linked to practical situations, rarely resulting directly from the legislation in force, but from its application in the specific case. The Commission, therefore, considers that it is necessary to examine the practices of the Member States acting on the principle of equal treatment in order to ensure that the Directive is effectively respected in national administrative practices.

The Commission has acknowledged that just the legislation is not enough to resolve the deep social exclusion to which Roma communities are exposed and must be supplemented by political and financial measures. It cites, as an example, the adoption of the "EU Framework for National Roma Integration Strategies up to 2020", on the basis of which the Commission has monitored the measures adopted by the Member States each year in the areas of education, employment, housing and care with the ethnic Roma community, including positive actions.

In addition, the Commission has proposed a Recommendation on Gypsies, adopted by the Council on 9 December 2013, which emphasizes the need to effectively implement the Directive in the day-to-day lives of these communities through the adoption by Member States of measures to ensure that their regulations are neither discriminatory nor segregating. The Commission concludes this point in the report by noting that, although there is a large pool of national jurisprudence

Employment Framework Directive 2000/78”, November 3 2008, http://www.era-comm.eu/ oldoku/Adiskri/07_Disability/2008_ODempsey-EN.pdf (accessed July 22, 2017).

${ }^{8}$ See Communication from the Commission to the European Parliament, the Council, the European Economic and Social Committee and the Committee of the Regions, an EU Framework for National Roma Integration Strategies up to 2020, $\operatorname{COM}(2011) 173$ final, Brussels, 5.4.2011 [available at http:// ec.europa.eu/health//sites/health/files/social_determinants/docs/com2011_173_en.pdf]. 
on this subject, the CJEU has not yet been called upon to rule on any case that specifically concerns the ethnic group of Roma.

So, from the analysis of the provisions of the Directive 2000/43/EC and the Commission's reports to the European Parliament and the Council in 2006 and 2014 about its implementation, the importance of the principle of equal treatment and combating discrimination on grounds of racial or ethnic origin is evident, especially when we consider the innovative nature of the directive, as well as its scope of application to situations which were not previously covered by European Union law.

The directive addresses the issue of racial or ethnic discrimination broadly, without defining such terms. However, in both the 2006 Communication and the 2014 report, the Commission has shown concern for the Roma people in view of the discrimination historically suffered by this group in several European Union countries. The Roma people continue to be the poorest ethnic group with a low level of schooling, subjected to precarious housing conditions and the main target group of racism and discrimination in European societies, often associated with the image of social and economic parasites, usually seen as elements that destabilize society, linked to forms of life of an unlawful character. ${ }^{9}$

As presented in the Commission's reports, Member States have taken significant steps forward in order to combat discriminatory practices against this ethnic group, as well as to promote better conditions of equality, such as through positive action. However, in spite of this effort, the Commission has shown that in many Member States, complaints and cases concerning racial or ethnic discrimination are mostly from Roma groups or individuals.

However, in spite of this statistical representation, no specific case on discriminatory practices involving Roma people has been highlighted by the Commission's report of 2014, adopted on 17 January 2014. That situation, however, changed one month later, on 17 February 2014, when a request for a preliminary ruling was lodged pursuant to Article 267 of the Treaty on the Functioning of the European Union in the case of CHEZ Raspredelenie Bulgaria AD v Komisia za zashtita ot diskriminatsia.

This request gave rise to case C-83/14, whose judgment by the CJEU (Grand Chamber) on 16 July 2015 examined the provisions of the Directive 2000/43/EC and have had a significant impact on the understanding of European Union law. Next, we will examine the arguments presented in that judgment and the conclusions of the Advocate General of the case, Juliane Kokott.

\section{Case $C H E Z$ (C-83/14) and the indirect discrimination by association}

The judgment of the CJEU in the case C-83/14, delivered on 16 July 2015, concerned a request for a preliminary ruling about the interpretation of i) Article 1 and Article 2(1) and (2)(a) and (b) of the Directive 2000/43/EC, implementing the principle of equal treatment between persons irrespective of racial or ethnic origin, and; ii) Article 21 of the CFREU.

The dispute in the main proceedings relates to the fact that, between 1999 and 2000, the CHEZ Raspredelenie Bulgaria AD - CHEZ RB, a Bulgarian electricity

\footnotetext{
${ }^{9}$ For further information see Maria Manuela Ferreira Mendes, "Nós, os Ciganos e os Outros: Etnicidade e Exclusão Social" (Lisboa: Livros Horizonte, 2005).
} 
distribution company, installed the electricity meters of all the consumers of the 'Gizdova mahala' district, of the town of Dupnitsa (Bulgaria), inhabited mainly by persons of Roma origin, on the concrete pylons forming part of the overhead electricity supply network at a height of between six and seven metres, whereas in the other districts, the metres installed by CHEZ RB are placed at a height of 1.70 metres, usually in the consumer's property, on the façade or on the wall around the property.

In December 2008, Anelia Georgieva Nikolova, owner of a grocery store in the 'Gizdova mahala' district, lodged an application with the Komisia za zashtita of dikriminatsia - KZD (Bulgarian Commission for Protection against Discrimination) alleging that she was suffering direct discrimination on the grounds of nationality due to the practice at issue of CHEZ RB.

Firstly, KZD ruled that the practice at issue constituted an indirect discrimination prohibited on grounds of nationality. However, after that decision was annulled by a judgment of the Varhoven administrativen sad (Supreme Administrative Court), KZD decided that Anelia Nikolova had suffered a discrimination because of her "personal situation" and ordered CHEZ RB to bring discrimination against her to an end and to refrain from such discriminatory behaviour in the future.

Against that decision, CHEZ RB brought an appeal before the Administrativen sad Sofia-grad (Administrative Court, Sofia), which decided to stay proceedings and to refer ten questions to the CJEU for a preliminary ruling. These questions were also examined by Advocate General Juliane Kokott in her Opinion.

As a starting point for its questions, the referring court considered that the case must be assessed in the light of the characteristics of "ethnic origin" Roma, common to the majority of the people living in the 'Gizdova mahala' district. However, the referring court had doubts as to whether it was a case of direct discrimination or indirect discrimination, as envisaged in Article 2 (2) (a) and (b) of the Directive 2000/43/EC respectively. Furthermore, if the practice at issue were to fall within the concept of indirect discrimination, the referring court asked whether it could be objectively justified and be deemed appropriate and necessary within the meaning of Article 2 (2) (b) of the directive.

Of the ten questions referred to the CJEU, in the first question, the referring court enquired about what the Advocate General Kokott called "the personal scope of the Council Directive 2000/43/EC'. ${ }^{10}$ Essentially, the referring court wanted to know which people are covered by the concept of "discrimination on the grounds of ethnic origin" for the purposes of the Council Directive 2000/43/EC. The prevailing view of the CJEU was that the scope of the Directive 2000/43/EC should not be defined in restrictive terms and that the directive applies equally to all persons who, although not belonging to the racial or ethnic group discriminated, suffer less favorable treatment or disadvantage on one of these grounds.

In this regard, the Advocate General, mentioning the decision in Coleman judgment, ${ }^{11}$ questioned whether Anelia Nikolova can be considered to be discriminated by association, when considering a measure which, by virtue of its general and collective nature, affects not only persons who have one of the characteristics referred to in Article 21 of the CFREU and in the anti-discrimination directives, but

\footnotetext{
${ }^{10}$ Opinion of Advocate General Kokott delivered on 12 March 2015, judgment CHEZ Raspredelenie Bulgaria AD v. Komisia za zashtita ot diskriminatsia, C 83/14, recital 42.

${ }^{11}$ Opinion CHEZ Razpredelenie Bulgaria, cit., recital 56; Judgment Coleman, July, 17, 2008, C-303/06.
} 
also other people as "collateral damage".

The CJEU in its judgment, without mentioning the term "discrimination by association", which was used by Advocate General Kokott, ruled on the referring court's first question; "that the concept of 'discrimination on the grounds of ethnic origin', for the purpose of Directive 2000/43 and, in particular, of Articles 1 and 2(1) thereof, must be interpreted as being intended to apply in circumstances such as those at issue before the referring court - in which, in an urban district mainly lived in by inhabitants of Roma origin, all the electricity meters are placed on pylons forming part of the overbead electricity supply network at a height of between six and seven metres, whereas such meters are placed at a height of less than two metres in the other districts - irrespective of whether that collective measure affects persons who have a certain ethnic origin or those who, without possessing that origin, suffer, together with the former, the less favourable treatment or particular disadvantage resulting from that measure". ${ }^{12}$

Considering the possibility of being a case of discrimination by association, the CJEU goes on to consider the other questions in which the referring court asks whether it is a case of direct or indirect discrimination.

About the direct discrimination, the CJEU understood that for this to exist, it is sufficient that ethnic origin has determined the decision to institute the practice at issue. In so far as it was not contested by CHEZ RB that the practice at issue was established only in the neighborhoods primarily inhabited by citizens of Roma origin, the CJEU ruled in its judgment "that Article 2(2)(a) of Directive 2000/43 must be interpreted as meaning that a measure such as the practice at issue constitutes direct discrimination within the meaning of that provision if that measure proves to have been introduced and/or maintained for reasons relating to the ethnic origin common to most of the inhabitants of the district concerned'. ${ }^{13}$

Regarding the possibility of the practice being a case of indirect discrimination, the CJEU points out that indirect discrimination may result from a measure that, despite its neutral formulation, because based on reference to other criteria not directly related to the protected characteristic, generates the disadvantage for people with this characteristic. The CJEU provides that, supposing the referring court concludes that the practice at issue is not a case of direct discrimination based on ethnic origin, the facts, as it has been established, suggest that the practice has the characteristics to constitute indirect discrimination within the meaning of Article 2 (2) (b) of the Council Directive 2000/43/EC, unless it can be objectively justified by a legitimate aim and the means of achieving that aim are appropriate and necessary. The CJEU argues that the tendency is to consider that the practice at issue could not be justified within the meaning of Article 2 (2) (b) of the Directive 2000/43/ EC, since the disadvantages caused by the practice appear disproportionate to the objectives pursued. However, it emphasises that it is for the referring court, in the context of a preliminary ruling procedure, to carry out the final assessments which are necessary in that regard.

The Advocate General, who considers that the case in question is, indeed, an indirect discrimination, questions whether the concepts of "indirect discrimination" and "discrimination by association" are legally compatible and whether the less favorable treatment given to Roma people in the 'Gizdova mahala' district can be considered as a sufficient basis for finding a case of discrimination by association of Anelia

\footnotetext{
${ }^{12}$ Judgment CHEZ Razpredelenie Bulgaria AD v. Komisia za zashtita ot diskriminatsia, July, 16, 2015, C $83 / 14$, recital 60 .

${ }^{13}$ Judgment CHEZ Rąpredelenie Bulgaria AD, cit., recital 91.
} 
Georgieva Nikolova, when the treatment is only indirectly related to the ethnic origin of the Roma group. According to the Advocate General, no specific structural features were claimed in the case of indirect discrimination under Article 2 (2) (b) of the Council Directive 2000/43/EC, which could preclude the possibility of a person being discriminated by association. So, in her view, it is possible to recognise the topic of discrimination by association related to indirect discrimination in the same way as for direct discrimination.

And that is what the CJEU has understood in its judgment. Although it did not use the term "discrimination by association" in its decision, all the reasoning developed by the Court allows such an understanding.

\section{Conclusion}

As explained in the development of this work, as a corollary of the principle of equality comes the prohibition of discrimination. These principles are developed in the most varied legal instruments of International Human Rights Law. In the context of the European Union, there are important directives in this area, in particular, the Directive 2000/43/EC implementing the principle of equal treatment between persons irrespective of racial or ethnic origin.

This directive has made important progress in promoting equality in general, since in broadening its scope beyond labour issues, it promotes an expansion of the understanding of issues related to discriminatory practices, exposing to the analysis situations and contexts sometimes not properly considered by the authorities of the Member States.

From this perspective, a better statistical, social and political analysis of the situations of racial or ethnic discrimination witnessed in the Member States was made possible even though a large number of them do not collect their ethnic data. What was provided by the European Commission has already made it possible to ascertain the most common discriminatory practices, which ethnic groups are most affected and which are the main obstacles faced by Member States and their national organisations in effectively promoting racial or ethnic equality.

As stated in the two reports of the European Commission studied here, among the elements that most gave rise to doubts among Member States in the transposition of the Directive 2000/43/EC are the notions of direct discrimination and indirect discrimination, of burden of proof and of positive actions.

In addition, it has been evident in both documents that one of the groups that suffers most from the issue of racial or ethnic discrimination is the group of Roma people.

In both cases, whether in the interpretative doubts concerning the provisions of the Directive 2000/43/EC or in relation to the issue of Roma people, what was discussed in case $C-83 / 14$ is of significant importance, namely the arguments of the CJEU and the conclusions of the Advocate General Juliane Kokott, since they provide a detailed argument to answer the questions put by the national court, bringing to the discussion, within the scope of European Union law, concepts such as "direct discrimination", "indirect discrimination" and "discrimination by association", whose interpretation by the CJEU influences the whole understanding of the national legal provisions in the Member States.

Therefore, the judgment in case $C-83 / 14$, as well as being an important case decided by the CJEU about the citizens of the Roma ethnic minority, is a milestone 
in the Court's case-law concerning the interpretation of the principle of equality in European Union law, ${ }^{14}$ since it had already recognized direct discrimination by association in the Coleman judgment. In the CHEZ judgment, the Court innovates by presenting the view that it is also possible to have indirect discrimination by association.

Although the CJEU did not use the term "discrimination by association" in its decision, all the reasoning developed by the Court allows such an understanding, in particular, when it answers the first question of the referring court as follows:

[t] he concept of 'discrimination on the grounds of ethnic origin', for the purpose of Council Directive 2000/43/EC of 29 June 2000 implementing the principle of equal treatment between persons irrespective of racial or ethnic origin and, in particular, of Articles 1 and 2(1) thereof, must be interpreted as being intended to apply in circumstances such as those at issue before the referring court - in which, in an urban district mainly lived in by inhabitants of Roma origin, all the electricity meters are placed on pylons forming part of the overhead electricity supply network at a height of between six and seven metres, whereas such meters are placed at a height of less than two metres in the other districts — irrespective of whether that collective measure affects persons who have a certain ethnic origin or those who, without possessing that origin, suffer, together with the former, the less favourable treatment or particular disadvantage resulting from that measure. ${ }^{15}$

Thus, when the CJEU states that the concept of "discrimination on grounds of ethnic origin" within the meaning of the Directive 2000/43/EC, is also applicable to persons who, without having a certain ethnic origin, suffer along with those who have it, a less favorable treatment or a particular disadvantage arising from a collective measure, it is understood that discrimination on grounds of ethnic origin under the directive, whether direct or indirect, also occur in cases of discrimination by association.

This understanding had a significant value for the case in question, especially regarding the protection of the Roma ethnic group against practices that are neutral in society, but which end up bringing a series of discriminations to this ethnic minority. ${ }^{16}$ However, in a broader picture, the position adopted by the CJEU in this judgment is even more important when considering the interpretation of European Union law and, consequently, of the national legal orders in the Member States. ${ }^{17}$

The understanding of the principle of equality as provided in Article 21 of the CFREU is broader, calling into question national provisions to better reflect the new

\footnotetext{
${ }^{14}$ For further information see Rossen Grozev,"A Landmark Judgment of the Court of Justice of the EU - New Conceptual Contributions to the Legal Combat against Ethnic Discrimination”, The Equal Rights Review, Vol. Fifteen (2015): 168-187, http://www.equalrightstrust.org/ertdocumentbank/A\%20 Landmark\%20Judgment $\% 20$ of $\% 20$ the $\% 20$ Court $\% 20$ of $\% 20 J$ ustice $\% 20$ of $\% 20$ the $\% 20$ EU $\% 20$ $\%$ E $2 \% 80 \% 93 \% 20$ New $\% 20$ Conceptual $\% 20$ Contributions $\% 20$ to $\% 20$ the $\% 20$ Legal $\% 20$ Combat $\% 20$ \%20against \%20Ethnic\%20Discrimination.pdf (accessed December 12, 2016).

${ }^{15}$ Judgment CHEZ Razpredelenie Bulgaria AD, cit., recital 129, No. 1.

${ }^{16}$ For further information see Open Society Justice Initiative, "EU Court Finds Bulgarian Electricity Company Discriminated against Roma”, July 16, 2015, https://www.opensocietyfoundations.org/ press-releases / eu-court-finds-bulgarian-electricity-company-discriminated-against-roma (accessed November 20, 2016).

17 For further information see James Tunley, "Race Directive Covers Associative Indirect Discrimination”, 4KBW, July 22, 2015, http://www.4kbw.net/news/22072015121520-racedirective-covers-associative-indirect-discrimination-/ (accessed November 19, 2016).
} 
interpretation of European Union law, thus making it possible for a number of legal situations which were not previously supported by the directives to enter the sphere of legal protection.

In the Opinion of the Advocate General Juliane Kokott, however, for those who suffer discrimination by association, it matters little if what is involved direct or indirect discrimination, since in both cases, they are "collateral damage" also. The difference would be in the possibility of justifying an unequal treatment in one case and another, because the objectives that are capable of being invoked to justify an indirect discrimination are broader and more diversified than those that justify direct discrimination.

Thus, the CJEU's decision in case C-83/14 in conceiving the possibility of indirect discrimination by association, as well as detailing the full understanding of what would be the concepts of "less favorable treatment", "comparable situation", "provision, criterion or practice that is apparently neutral" and "a disadvantageous situation" under the Directive 2000/43/EC, provides important answers to the interpretation of European Union law and at the same time, it raises a number of questions about the extent to which it will take in the resolution of complex cases.

After the judgment of the CJEU in case C-83/14, many doubts have arisen by claiming the "dangerous magnitude" of such an understanding when considered from an apparently neutral practice. But that ends up putting a person endowed with one of the characteristics listed in Article 21 of the CFREU or in anti-discrimination directives in a situation of disadvantage compared with other persons, and an individual, who has no link with the person who is the object of the practice at issue, invokes legal protection for suffering "collateral damage". ${ }^{18}$ In this sense, there was a fear that the legal protection of discriminatory practices would be so expanded that lawsuits that have little legal support will be taken to court and so that the protection of material equality becomes fragile. ${ }^{19}$

However, one cannot question the idea of "indirect discrimination by association" at this point, supposing a misuse of legal devices and their consequent trivialisation. It is necessary to take account of the fact that, in today's world, where the control of moral and legal parameters is increasingly intense, the tendency is to cultivate the practices that, with the appearance of neutrality, end up violating a series of rights. This is mainly seen in cases involving discrimination based on race, sex, sexual orientation and colour, since they are usually practices involving a supposed aspect of neutrality, giving as justification other reasons, but that, ultimately, end up treating individuals unequally.

In addition, the notion brought by the CJEU ruling in case C-83/14 is also relevant in the current context in which the discussion on citizenship of the European Union is gaining new contours in the face of the intense migratory flow and the consequent questions about multiculturalism, cultural identity, social integration, and national security. After all, the issue of racial and ethnic diversity has always been a central element in the discussion of European Union citizenship, in view of the

\footnotetext{
${ }^{18}$ For further information see Amanda Steadman, "EU discrimination law protects individuals against associative indirect discrimination" Lexology, August 21, 2015, http:/ /www.lexology.com/ library/detail.aspx?g=37ffe336-5801-4b70-9624-ec28f7a72af1 (accessed November 20, 2016).

${ }^{19}$ For further information see Frank Cranmer, "Discrimination, equal treatment, electricity and collateral damage: CHEZ Råpredelenie Bulgaria”, Law \& Religion UK, September 9, 2015, http:// www.lawandreligionuk.com/2015/09/09/discrimination-equal-treatment-electricity-and-collateraldamage-chez-razpredelenie-bulgaria/ (accessed November 20, 2016).
} 
interaction of Member States in an increasingly globalised world.

Thus, the possibility of the Directive 2000/43/EC also encompassing indirect discrimination by association brings even more elements of complexity to the subject of European Union citizenship by highlighting possibilities of racial discrimination or ethnic origin that call into question the principle of equal treatment in the effective protection given to the citizens of the European Union, since, as we have seen, despite being formally endowed with equal rights and duties, citizens of the European Union with different racial or ethnic origins are still subject to different treatment.

The judgment of the CJEU in case C-83/14 has already given rise to a series of discussions between European Union lawyers and practitioners about how the Court's approach will influence the legal orders in the Member States and their societies and customs on the complex issue of discrimination. The ability of the CJEU's decisions to influence changes in national legal orders is undeniable. Thus, what is to be seen is how such changes will occur in a context marked by a migratory crisis in Europe, which is advancing with a series of conservative movements in political orders.

In that sense, the CJEU's decision, in bringing its broader understanding in the field of discrimination, challenges this context by moving the entire legal apparatus of the European Union and its Member States towards the realisation of the principle of equal treatment between people, without discrimination of any kind on grounds of sex, race, color, ethnic or social origin, genetic characteristics, language, religion or belief, political or other opinion, membership of a national minority, wealth, birth, disability, age or sexual orientation. 